\section{Vuyokazi Nomlomo}

University of Western Cape,

Faculty of Education,

Modderdam Road, Bellville,

7535. Email:vnomlomo@uwc.

ac.za; Cellphone: 0827981797

\section{Zilungile Sosibo}

Cape Peninsula University

of Technology, Faculty of

Education, Mowbray, 7770.

Email: SosiboL@cput.ac.za;

Cellphone: 0710701266

DOI: http://dx.doi.

org/10.18820/2519593X/pie.

v34i1.14

ISSN 0258-2236

eISSN 2519-593X

Perspectives in Education

2016 34(1): 199-215

(c) UVIUFS

\section{From theory to practice: Beginner teachers' experiences of the rigour of the Postgraduate Certificate in Education programme}

\begin{abstract}
This article focuses on how recent graduates perceive the rigour of the Postgraduate Certificate in Education (PGCE) initial teacher education (ITE) programme. The article is based on qualitative data collected from a purposely selected sample of 19 beginner teachers who graduated from two higher education institutions that offer PGCE programmes in the Western Cape. Data were primarily collected by means of open-ended semi-structured interviews and triangulated through document analysis. Results revealed how beginner teachers' conceptions of rigour of the ITE programme differ considerably from those advocated by experts on teacher education. The authors of this paper recommend that if rigour in teacher education programmes is to be understood, voices of student teachers and other stakeholders (e.g. teachers, school principals, communities, policy makers) should be included in the design and development of teacher-education curricula. Inclusion of these voices might constructively complement existing conceptions of rigour and influence ITE curriculum policy for the benefit of all stakeholders. Nonetheless, it should be borne in mind that some of these conceptions of rigour might not be informed by theoretical underpinnings and can therefore not supersede those of the experts.
\end{abstract}

Keywords: Initial teacher education, rigour, beginner teachers, Postgraduate Certificate in Education (PGCE), policy

\section{Introduction and background}

During the apartheid era, initial teacher education (ITE) in South Africa was offered in teacher training colleges that were racially segregated (Pournara, 2009). The new democratic dispensation that followed the demise of the apartheid system in 1994 brought many changes in higher education and teacher education. Within this dispensation, the Department of Education (1997), through its notice 1196 of 1997, White Paper 3: A Programme for the Transformation of Higher Education in South Africa transformed the education system by introducing new curricula underpinned by principles of access, redress and social justice (Sayed \& Motala, 2012; Kanjee, Sayed \& Rodriguez, 2010). Two major changes in higher education were the integration of 
teacher training colleges into universities (Pournara, 2009) and the upgrading of Teachers' Certificate, Diploma and Higher Diploma courses into two qualifications: the Bachelor of Education (B.Ed.) and Postgraduate Certificate in Education (PGCE) (Department of Higher Education and Training [DHET], 2011: 15).

Whereas the B.Ed. is a four-year degree, the PGCE is offered full-time over one year or part-time over two years after a bachelor's degree or equivalent diploma. Both qualifications are pegged at level 7 on the Higher Education Qualifications Sub-Framework (DHET, 2015). They focus on the application of different kinds of teacher knowledge which student teachers are expected to demonstrate by the time they obtain their teaching qualifications (DHET, 2011:15; 2015:19). The B.Ed. degree carries a minimum of 480 credits while the PGCE carries 120 credits. This is because a three-year undergraduate degree of 360 credits or an approved diploma is a prerequisite for students' entry into the PGCE programme (DHET, 2011). Students with these qualifications should have acquired sufficient content knowledge in a teaching subject to be admitted into the PGCE programme. However, they still need to develop their pedagogical and practical knowledge to apply in real classroom contexts (DHET, 2011, 2015). Consequently, PGCE students are required to spend between eight and twelve weeks in schools for supervised and assessed teaching practice.

Concerns have been raised regarding low teacher quality and low quality of teaching and learning in schools usually associated with poor teacher education (Sosibo \& Nomlomo, 2014; Madisaotsile, 2012). Given the short duration and lower minimum credit value of the PGCE programme compared to its B.Ed. counterpart, the authors of this paper suspected that the PGCE might not provide students with optimum rigour to prepare them adequately to acquire, integrate and confidently apply the different kinds of teacher knowledge required in the workplace. Our understanding of the minimum requirements for teacher education qualifications (MRTEQ) and its focus on integrated TE knowledge guided our conceptualisation of rigour (DHET, 2011, 2015). Furthermore, current academic literature on how beginner teachers navigate their academic and professional identities as they learn to teach also guided our conceptualisation of rigour (Kemmis, 2011; Fitzmaurice, 2010; Rusznyak, 2009; Ashby, et al., 2008; Darling-Hammond \& Bransford, 2005). We therefore adopted the meaning of rigour as in-depth pedagogical and practical knowledge that student teachers should acquire during their pre-service teacher education programmes and that practising teachers can apply in a variety of teaching and learning contexts. Such knowledge includes being innovative, critical and reflective practitioners (Kemmis, 2011; Reyes \& Fagan, 2010).

In light of the above, we investigated newly graduated teachers' conceptions of rigour in the PGCE programme. We focused our attention on PGCE graduates (referred to as beginner teachers) who had completed their qualification in 2014. Our assumption was that as newly qualified teachers, they would provide us with fresh perspectives on the rigour of this programme, as influenced by their recent entry into the field of teaching. We wondered whether their voices would be invaluable in strengthening the PGCE programme and in influencing policy on the rigour of these programmes. Our research question was: "How do beginner teachers perceive the rigour of the PGCE programmes?"

The next section comprises literature related to the complexity of learning to teach. This literature supports the view that learning to teach is not a simple, mechanistic and one-way process but is fraught with complexities. 


\section{The complexity of learning to teach}

There is abundant literature that shows that learning to teach is a complex process. Emphasising the complexity related to learning to teach, Hammerness et al. (2005: 368) state that, "Even when observing good teaching or experiencing it for oneself, one cannot easily glean a deep understanding of the complexity of the work". This is because student teachers enter teacher education with deeply entrenched and sometimes limited conceptions of teaching and learning which they acquire during their own experiences of schooling (Lawrence \& Butler, 2010; Hammerness et al. 2005; Britzman, 2003; Feiman-Nemser, 2001a). In Hammerness et al., (2005: 359) it is argued that these conceptions are based on student teachers' "apprenticeship of observation" when they observe teaching without an insider's knowledge of the practices of teaching. These notions are difficult to eliminate and they tend to block students from acquiring new knowledge (Hammerness et al., 2005). They range from perceiving teaching as easy or as standing in front of students and imparting knowledge (Britzman, 2003; Feiman-Nemser, 2001a) to learning as a simple, mechanistic and one-way transfer of information from teacher to learner (Lawrence \& Butler, 2010).

Contrary to these notions, student teachers need to understand that learning to teach is incredibly complex and demanding and includes a wide variety of teacher knowledge for them to master before they graduate (Lawrence \& Butler, 2010; Hammerness et al., 2005; Cochran-Smith, 2001; Feiman-Nemser, 2001a, b; Shulman, 1987; Morrow, 2007). Kerry and Mayes (1995) contend that learning to teach involves the development of different theoretical and practical knowledge, cognitive changes and interpersonal and affective skills. This development helps student teachers to grow intellectually, aesthetically, affectively and socially. Hammerness et al. (2005: 358) also add understanding of subject matter, learning, development, culture, language, pedagogy, assessment, attitudes and addressing individual needs of diverse learners to the requirements of learning to teach. Thus, learning to teach is a complex and cognitively demanding practice that requires more than mere observation and emulating what students' teachers did in the classroom.

Over and above the problem of complexity is the problem of enactment. Hammerness et al., (2005: 359) allude to "the problem of enactment" which involves learning to multitask or to do various things simultaneously and to integrate the different types of knowledge into coherent practice. Feiman-Nemser (2001a: 1016) focuses on developmental skills of students which portray the problems of complexity and enactment in teaching. According to her, the different types of teacher knowledge that student teachers have to integrate and enact include (i) analysing preconceived notions of teaching and learning, (ii) developing subject matter and pedagogical knowledge, and (iii) developing an understanding of learners' developmental stages and socio-cultural contexts. It also includes (iv) developing a beginning repertoire or acquisition of different pedagogical skills and ( $v$ ) developing tools to study teaching requiring skills of observation, interpretation, analysis and research. This classification demonstrates that learning to teach is a developmental process that happens through various stages.

Several stage models have described students' progression from novice to expert (Lawrence \& Butler, 2010; Feiman-Nemser, 2001a; Hammerness et al., 2005; Berliner, 2004; Kerry \& Mayes, 1995). Feiman-Nemser (2001a) argues that they derive from students' personal and situational factors. Kerry and Mayes (1995) categorise these stages into early idealism, survival, recognising difficulties, hitting the plateau and moving on. In Feiman-Nemser (2001a), it is perceived as progressing in a continuum from concerns about self, teaching and learning. 
Berliner's (2004) description includes a range of characteristics: from being a novice, advanced beginner, competent, proficient and expert, which illuminates fluidity of performance in teaching. Students are also defined as preoccupied with themselves and their actions as teachers rather than focusing on learners' actions and learning (Lawrence \& Butler, 2010). Granted, grouping student teachers or beginner teachers into these categories may undermine their diversity and the fact that while some may need assistance, others may bring rich experiences accumulated from diverse contexts.

Unlike the developmental stages of learning to teach mentioned above, Shulman (1987) and Morrow (2007) emphasise knowledge for practice, which is acquired mainly in university classrooms. Shulman (1987) classifies teacher knowledge into seven domains. The content knowledge domain or subject matter knowledge, (Shulman (1987: xiii) requires that teachers must "be well educated, especially in the subject matter content they teach..." Shulman identifies general pedagogical knowledge as a combination of classroom management, organisational principles and strategies. Curriculum knowledge involves an understanding of materials and programmes that serve as tools of the trade for teachers. Pedagogical content knowledge (PCK) combines content and pedagogical domains. Shulman proposes knowledge of learners and their cultures, characteristics and needs. Such knowledge is crucial because learners' backgrounds are so heterogeneous. According to Shulman, knowledge of educational ends, purposes, values and their philosophical and historical grounds is equally crucial. Knowledge of varying educational contexts is equally significant, since learners' schooling backgrounds differ so considerably.

Like Shulman, Morrow (2007: 82) argues that "content knowledge is a precondition for any teaching" but on its own, it is never enough. He believes that over and above content knowledge, students should also work with the formal elements of teaching to prepare them for the professional functions of organising learning systematically within the possibilities and constraints of the context. His concern is that the conception of teaching transcends the context-specific (or 'material') elements of teaching. Both Shulman and Morrow believe that university classrooms should provide student teachers with the kinds of teacher knowledge and skills that enable new teachers to enable learning. With the short period of time in which the PGCE programme is offered, for students to be provided with the rigour needed in both knowledge types might be a tall order. This is what this study purported to investigate, whether the PGCE programme provided newly graduated students with rigour and what their conceptions are of this concept.

Over and above knowledge-for-practice presented earlier, Cochran-Smith and Lytle (1999) classify teacher knowledge into knowledge-in-practice and knowledge-of-practice. They claim that knowledge-in-practice is grounded in the profession. Newly graduated teachers, including the participants in this study, acquire this knowledge in the workplace.

The role of knowledge-of-practice (teaching practice) cannot be overlooked in a discussion of rigour in teacher education. Darling-Hammond and Bransford (2005) maintain that student teachers need to be exposed to expert knowledge and reflective practice as they develop their professional identity. For this to occur, student teachers need constant supervision, coaching and constructive feedback from experienced teachers and mentors to assist them to understand and apply the different kinds of knowledge in the classroom and to reflect on their practice (Darling-Hammond \& Bransford, 2005). In this way they make a deeper sense of the 
concepts they have learnt in their university-based courses and adapt their knowledge and practice to different situations (Grosser \& De Waal, 2008).

A debate continues to rage over the role of apprenticeship in the process of adding rigour to the teacher education curriculum. Some arguments point to the fact that teaching practice alone is not enough to make a competent teacher. Lortie's (1975) work, for example, supports the view that the numerous observation hours spent by student teachers in the field contributes to the configuration of their system of belief in education and also helps them to interpret their own experiences in teacher education. With the limited hours that PGCE students spend in schooling contexts, there are questions regarding whether the programme provides them with rigour to reflect and configure their attitudinal and belief systems.

For students to acquire sufficient skills in knowledge-of-practice, 'good' teaching practice placements need to occur. LaBoskey and Richert (2002: 8) define a 'good' teaching practice placement as one that provides students with a "generally positive and productive learning experience" and in which students have multiple opportunities to:

- recognise the principles in action, that is, teachers modelling teaching behaviours and practices and reflect (in and on action, i.e. during and after action)

- enact teaching principles

- embrace teaching principles to guide future teaching.

LaBoskey and Richert (2002: 27) found that 'better' placements in which most student learning occurred were in contexts where "a composite (or blending) of the principles (i-iv) above was present". Nevertheless, there is literature that alludes to the fact that teaching practice may bring negative experiences to the student teachers, depending on the context of the schools in which they are placed. For example, Buehler et al. (2009) report that placements of students in schools with a diverse student body can present challenges for student teachers to learn to teach.

In this section, we have presented literature that shows that learning to teach is a complex process that requires student teachers to have a sound knowledge base in theoretical and practical knowledge. The following discussion provides a summary of how rigour in an ITE curriculum is understood in current academic discourses. The discussion in this section foregrounds how beginner teachers conceive rigour and it forms the basis for analysis of beginner teachers' understandings of this concept in relation to the PGCE ITE programme.

\section{Understanding academic rigour in ITE programmes}

As shown earlier, learning to teach is a dynamic and complex process that integrates different kinds of knowledge domains (DHET, 2011, 2015; Kemmis, 2011). How teacher knowledge is defined is based on an institution's philosophy of what constitutes rigour in teacher education (Blömeke \& Kaiser, 2014). An understanding of these bases is crucial, as they constitute what policy makers and experts refer to as depth and rigour in teacher education. Verloop, Van Driel and Meijer (2001: 443) provide an all-encompassing definition of a teacher knowledge base as "all profession-related insights that are potentially relevant to the teacher's activities". Ben-Peretz (2011: 8) break this base down to "knowledge of general pedagogical principles and skills and knowledge of the subject matter to be taught". In other definitions, teacher knowledge is classified into elaborate categories that include subject 
matter/content, curriculum, pedagogy, contexts, learners, formal and material elements of teaching (see, for instance, Cochran-Smith \& Lytle, 1999; Feiman-Nemser, 2001a).

While teacher knowledge domains provide a theoretical framework of what constitutes rigour in teacher education, there is no single definition of the concept of rigour. Reyes and Fagan (2010) define academic rigour as a complex entity associated with an integrated body of knowledge that stimulates students' higher order thinking and active engagement in learning. Academic rigour requires multiple perspectives of teaching and learning strategies that enhance students' epistemological access to knowledge (Jacobs \& Colvin, 2010; Slonimsky \& Shalem, 2006). These strategies include discovery, problem-solving, investigation, openended learning processes and an authentic application of knowledge in relevant settings (Reyes \& Fagan, 2010). Academic rigour requires students to apply and analyse knowledge in a way that reinforces "deep learning" through critical inquiry, and self-reflection which in turn instils life-long learning skills (Jacobs \& Colvin, 2010).

Curriculum design is one of the key elements of academic rigour (Slonimsky \& Shalem, 2006; Jacobs \& Colvin, 2010). Its goals, courses and activities, including pedagogy, assessment and feedback, should provide students with access to meaningful learning by focusing more on the depth than the breadth of learning (Reyes \& Fagan, 2010). This implies that the curriculum should be designed in a manner that fosters student-centred approaches, which challenge students to take risks and confront their personal beliefs and assumptions about learning (Reyes \& Fagan, 2010; Fitzmaurice, 2010). The curriculum must prepare students for their academic success in the world of work (Jacobs \& Colvin, 2010). It has to be responsive to society's sociocultural, political and economic contexts by producing skilful and innovative employees who are able to compete in the global marketplace (Slonimsky \& Shalem, 2006). These competencies are embedded in Slonimsky and Shalem's (2006) notion of curriculum responsiveness that takes into account the needs of the students with respect to their socio-historical environment and the nature of knowledge or practices to be learnt or mastered. Slonimsky and Shalem (ibid) refer to cultural, curriculum and learning responsiveness to emphasise that instructional strategies should cater for a diversity of students while deepening their knowledge and learning in specialised areas (Slonimsky \& Shalem, 2006) and ensuring collaboration, flexibility and high quality of learning (Jacobs \& Colvin, 2010). In ITE, rigour should be understood in relation to theory and practice because what and how student teachers learn to teach determines their actual practice in the classroom (Darling-Hammond \& Bransford, 2005).

Morrow (2007) adds acquisition of the formal elements of teaching to the discourse of rigour as another factor contributing to academic rigour in ITE. By this, Morrow means knowledge and skills of organising learning experiences systematically. In support of Morrow, Marcelo (2009: 12) argues, "organisation of knowledge helps experts to understand when, why and how the vast knowledge they possess should be used in a given situation". Morrow (2007: 100) further contends that in our teacher education programmes "we repeatedly define the work of teachers in terms of its material elements". This means that teacher education programmes are context-bound: they mostly prepare teachers to teach specific learning areas in a specific phase using certain approaches, thus limiting teachers to specific contexts. Consequently, they (teachers) cannot be able to function in contexts that do not comply with what they were taught. During training, students need to be provided with rigour in formal and material elements to allow them to be competent teachers. 
In the next section, the national policy on the minimum requirements for teacher education qualifications (MRTEQ) (DHET, 2015) framework is presented. Since it undergirds ITE programmes (including PGCE) in South Africa, the MRTEQ framework sets out standards for the depth and rigour required in the design and development of these programmes. A brief synopsis of this framework is essential.

\section{The national policy on the minimum requirements for teacher education qualifications (MRTEQ) framework}

There are diverse views on what constitutes quality in ITE programmes. Decisions on what counts as quality are made on the basis of the duration of the programme, time spent in schools for teaching practice (TP) by students and competences demonstrated by student teachers is often determined by authorities (e.g. policies) and providers of the qualifications, that is, universities, colleges or private institutions (Hoban, 2004). The common global concerns about ITE programmes include the nature of the curriculum and whether it produces the kind of intended teacher (graduate attributes). Other concerns include the university culture, quality of TP supervision by teacher educators, as well as teacher educators and students' identity, beliefs and conceptions of teaching (Darling-Hammond \& Bransford, 2005; Hoban, 2004).

As a guiding principle to TE programmes, it is important to refer to the national policy on the MRTEQ framework (DHET, 2011, 2015) in this paper. The MRTEQ framework provides guidelines on the scope, depth and rigour that inform the design and development of ITE programmes in South Africa. This framework constitutes the fundamental principles outlining admission requirements, exit outcomes or competences to be demonstrated by student teachers when they enter the teaching profession as beginner teachers, the design of the ITE programmes and the different kinds of teacher knowledge domains that should be included in the curriculum of teacher education programmes, including the PGCE programme. These domains include disciplinary, pedagogical, practical, fundamental and situational knowledge (DHET, 2011, 2015).

The MRTEQ framework was instituted because there was no national curriculum for TE in South Africa. Consequently, this policy guides higher education institutions (HEls) offering teacher education in the design of their own curricula (Kwenda \& Robinson, 2010). Attainment of exit outcomes or graduate attributes in teacher education programmes is prioritised (Fitzmaurice, 2010: 45). These outcomes include sound subject knowledge, ability to teach, an understanding of individual learner needs, understanding diversity and an ability to reflect on own practice (DHET, 2011, 2015). The MRTEQ framework, which is research driven, seeks to improve graduate attributes of student teachers so that they are thoroughly prepared by the time they become credentialed teachers. Regarding the PGCE programme, the MRTEQ policy requires students to have an in-depth and focused or specialised knowledge and practical skills that should enable them to apply it in schools in varying contexts (DHET, 2015).

\section{Research methodology}

This article is based on a qualitative case study conducted in the Faculties of Education offering the PGCE qualification at two higher education institutions (HEls A and B) in the Western Cape. The sample comprised 19 beginner teachers purposely selected from the 2014 graduation lists of these HEls. By the time of data collection, all of them were already employed in different schools in the Western Cape. Although 50 names were initially drawn from the HEls' lists of 
qualifying students, only 19 beginner teachers accepted the invitation to participate in this study. The advantages of having a small sample were that the group could easily be managed and in-depth interactions with participants could be conducted. This assisted us in determining how beginner teachers understood and described the rigour of the PGCE programmes in relation to their teaching experiences in the schools where they were employed.

Of the 19 participants, ten had obtained their PGCE qualifications from institution A and nine from institution $B$. The sample was mixed racially; comprising four white, nine coloured (mixed race) and six black beginner teachers. Of the ten participants from institution $A$, six were females, with two of each being white, coloured (mixed race) and black and four males consisting of one white and three coloureds as illustrated in the table below.

Table 1: PGCE students' biographical information

\begin{tabular}{|c|c|c|c|c|c|}
\hline \multicolumn{3}{|c|}{ Institution A } & \multicolumn{3}{|c|}{ Institution B } \\
\hline Race & Male & Female & Race & Male & Female \\
\hline White & $\begin{array}{l}1 \\
\text { Andre }\end{array}$ & $\begin{array}{l}2 \\
\text { Stacy } \\
\text { Caroline }\end{array}$ & White & $\begin{array}{l}1 \\
\text { Charl }\end{array}$ & 0 \\
\hline Coloured & $\begin{array}{l}3 \\
\text { Marvin } \\
\text { Herman } \\
\text { Dill }\end{array}$ & $\begin{array}{l}2 \\
\text { Delcia } \\
\text { Nirri }\end{array}$ & Coloured & 0 & $\begin{array}{l}4 \\
\text { Shakira } \\
\text { Maria } \\
\text { Fadillah } \\
\text { Rosette }\end{array}$ \\
\hline Black & 0 & $\begin{array}{l}2 \\
\text { Bhekisile } \\
\text { Thobeka }\end{array}$ & Black & $\begin{array}{l}1 \\
\text { Tsakane }\end{array}$ & $\begin{array}{l}3 \\
\text { Bongeka } \\
\text { Nomvuyo } \\
\text { Ncediwe }\end{array}$ \\
\hline TOTAL & 4 & 6 & & 2 & 7 \\
\hline
\end{tabular}

The breakdown of the nine participants from institution B revealed seven females consisting of four coloureds and three blacks as well as two males one being white and the other black. Their ages ranged between 23 and 36 years. Ethical considerations with regard to voluntary participation, anonymity and confidentiality were adhered to during the data collection process. In this article, pseudonyms were used to conceal and protect the identity of participants.

Data were collected through semi-structured, open-ended interviews, with each interview lasting approximately 45 minutes. The interviews elicited information regarding how beginner teachers understood the notion of rigour in the PGCE programme in relation to the knowledge acquired and their professional experiences and practices. The researchers made a concerted effort to include the voices of diverse participants. Where common views were expressed, the researchers selected them in a manner that would represent the diversity of participants according to race, gender and age.

Document analysis entailed examining the MRTEQ (DHET, 2011, 2015) and syllabus entries for PGCE programmes in the two HEls. The purpose was to understand the kinds of teacher knowledge and competences that were emphasised in the PGCE programmes in 
the two HEls. This exercise provided a deeper insight into the type of knowledge students were expected to acquire with reference to the knowledge they were exposed to and their experiences in relation to the curriculum content and its delivery in the programme. Interviews and document analysis were used for triangulation and to increase the chances of credibility of the research findings (Babbie \& Mouton, 2001: 20).

Recordings of the interviews were transcribed and coded before analysis. Data analysis took a thematic form. Data were categorised according to the aims and questions that guided the study. Two themes emerged from the data analysis: (i) beginner teachers' understanding of the rigour of PGCE programmes and (ii) gaps in the rigour of PGCE programmes, as perceived by beginner teachers in relation to how they experienced the university curriculum compared to their real classroom experiences.

\section{Research findings and discussion}

\section{Beginner teachers' understanding of the rigour of the PGCE programme}

As pointed out earlier, HEls have autonomy to design their curriculum which is often underpinned by research in pre-service teacher education and shaped by policy directives (Kwenda \& Robinson, 2010) such as MRTEQ. Given the differences in the institutional priorities and contestations about the relative importance of knowledge-for-practice and knowledge-in-practice, it is therefore not surprising that participants from the two institutions identified different modules that they believed had helped to shape their professsional development. Of importance is the fact that even though the modules were not similar, they encompassed the required types of teacher knowledge as informed by the two institutions' graduate attributes. Based on their utterances, ten beginner teachers who had graduated from institution A perceived to have benefitted from the knowledge and skills they had gained from their core curriculum that included language communication, ICT, research, education and life orientation. Bhekisile, one of the graduates from institution A expressed her view of these courses thus:

The combination of the major subjects in our PGCE programme gave me the depth I needed as a future teacher and researcher. My thorough understanding of these subjects made it easy for me to develop a research topic. Doing research and finding a research topic helped me to see the link between these different subjects.

Marvin, one of the three beginner teachers who had graduated from institution A, explained that the skills they had acquired from these modules helped them to solve problems related to teaching in $21^{\text {st }}$ century environments. Thus, one can assume that for Marvin, problemsolving skills constituted rigour in PGCE. Marvin's statement seems to reflect the curriculum responsiveness as suggested by Slonimsky and Shalem (2005).

Beginner teachers who had graduated from institution B highlighted language communication, psychology of teaching and learning, authority and discipline identities, learner achievement levels, education practice and teaching methods. These courses were identified as being indispensable for them as beginner teachers. The participants believed that the PGCE programme had provided them with intense rigour in these knowledge domains. In both cases, the depth and breadth of the programme offerings appeared to be key factors that students interpreted as the rigour they needed to enter the workplace. Clearly, as practising teachers, their basis of analysis of the rigour of the PGCE programme must have been 
informed by their university classroom and field experiences (as student teachers and as certified teachers), as well as the amount of time spent on these modules while at university. These teachers' conceptions of rigour align with Slonimsky's and Shalem's (2006) notion of disciplinary responsiveness, which entails students' immersion in specialised knowledge.

All the participants $(100 \%)$ commended the PGCE programme for the richness of the knowledge they claimed to have gained in particular from the pedagogical knowledge domain. To express his view, Herman, a graduate from institution A stated that:

Our subject didactics lecturers were really good and able to cover the teaching methods that span over wide teaching areas. I really can't complain even though I wish the [teaching] periods were longer. At least I can always refer to the knowledge I gained from those classes.

In the discussion of rigour in ITE presented earlier, theory is as important as practice in the process of learning to teach. Students acquire cognitive or theoretical knowledge of teaching in university classrooms and transfer it to the real classrooms. The challenge is for teacher educators to provide students with deep learning on how to link theory and practice. One of the ways to enhance rigour is through modeling. Students observe and imitate more skilled members of the Community of Teaching Practice - CoTP (Lave \& Wenger, 1999). Videos are an effective method of assisting students to acquire rigourous skills to become effective members of the CoTP.

Twelve of the 19 participants, with seven from institution A and five from institution B constituting of a mixture of race and gender categories agreed that the PGCE programme had introduced them to new educational concepts and skills, including critical thinking, creativity, problem-solving and decision-making. These skills were embedded in the different types of knowledge they were exposed to in the classroom, e.g. pedagogical and practical knowledge. They mentioned that these skills had not been highly emphasised in the high schools which they had attended. These skills are congruent with Reyes and Fagan's (2010) definition of academic rigour. They provide beginner teachers with a cognitive map, which supports their learning and enables them to see a relationship between different domains of knowledge (Darling-Hammond \& Bransford, 2005). In this way, beginner teachers acquire new skills and strategies to help them become independent thinkers, thus drawing them closer to the centre of the CoTP where they can apply these skills in real classroom contexts. A combination of these skills (Reyes \& Fagan, 2010) provide students with the rigour they need to facilitate their entry into the CoTP.

\section{Perceived gaps in the depth and rigour of PGCE programmes}

The majority of the beginner teachers commended the PGCE programme for its rigour. However, 13 of the 19 participants (approximately 68\%) representing all race and gender groups highlighted the hollowness of the situational domain of the PGCE. Eight of these participants were from institution A and five were from institution B. Tsakane (from institution B), described how this situation affected her efficacy as a teacher by referring to "normal children" and "normal schools" that reflect the socio-economic factors that influence teaching and learning in many South African schools.

When I studied PGCE, the programme did not prepare me at all for teaching in a druginfected and impoverished school like XXX where I teach. The programme prepared us for teaching normal children in normal schools but not what I have to deal with everyday. 
Participants intepreted their limited exposure to situational knowledge as a lack of rigour needed in ITE. In other words, the PGCE programme did not provide them sufficient opportunities to explore teaching in varying contexts. Academic rigour in the situational knowledge domain is essential to enable the students to integrate and apply the theoretical knowledge they acquired in university in real classroom contexts. As stipulated in MRTEQ, situational knowledge or knowledge about contexts, situations, settings or environments equips students with such skills (DHET, 2011; 2015). Students need exposure to situational knowledge in order to acquire the rigour, which is much needed in ITE and develops the students into self-reflective practitioners (Schön, 1987). Tsakane and other participants' concern about limited situational knowledge raises issues about what (should) constitute teacher education knowledge. Nonetheless, while the MRTEQ policy includes knowledge about contexts and learners, Morrow (2007) warns about overemphasis of specific teaching contexts over other knowledge domains. As shown earlier, student teachers need a balance between conceptual and contextual knowledge.

Both groups referred to the richness of the programme with regard to the diverse teacher knowledge they had acquired from the PGCE programmes from which they had graduated. However, five participants, two from institution $A$ and three from institution $B$ associated the short span of the PGCE programme with a lack of rigour. Their common concern seemed to be that the short duration of the programme put them under pressure and created a knowledge overload for them. Consequently, they agreed that they could not adequately assimilate and process the high volume of information and knowledge in what one of them referred to as a 'rushed programme'. For example, Maria's response from institution B can be understood in relation to the problem of enactment as she struggled to integrate the different kinds of knowledge. She stated that:

The [PGCE] programme is too overloaded. All the lecturers gives (sic) you lots of work and it is overwhelming ... there is no space to breathe. There was a time when I was just submitting the tasks although I could not make sense of anything, but I just wanted to hand in the work, even if I did not understand what I had to do.

It can be argued that rigour is not to be equated with a demanding curriculum. Rather, a rigorous curriculum is "focused, coherent and appropriately challenging" (Colvin \& Jacobs, 2010: 8). Granted, this situation might have obstructed beginner teachers' acquisition of deep learning through critical inquiry, self-reflection, creativity and critical thinking that are advocated by Jacobs and Colvin (2010) as constituting rigour. It might also have deprived them of opportunities to acquire other requisite knowledge and skills, thus consigning them to the periphery of practice and impeding their progression to the centre of the CoTP. If teacher knowledge domains were presented in a coherent and integrated manner, this would enable the teachers to develop a holistic rather than compartmentalised and fragmented view of teacher knowledge. Rusznyak (2015) warns about the danger that may occur if knowledge selection for compulsory courses is not informed by an overarching framework that makes it coherent. Citing Hoban (2006), Rusznyak (2015: 8) argues that when no framework exists, "they [students] find it difficult to make sense of the relationship between the different courses they do". The situation highlighted by Maria may imply that in the PGCE programme from which she graduated, quantity is emphasised over quality or connectivity. Yet, without doubt, rigour implies quality as opposed to quantity. The fact that Maria states that she was just submitting work without making sense of it is disconcerting, as it might suggest that the PGCE programme did not prepare her and other participants to apply and evaluate knowledge and 
to reflect and translate it into practice in the classrooms. Yet, reflection is important for growth and development (Lave \& Wenger, 1999; Schön, 1987), as it provides beginner teachers with opportunities to identify problem areas and alternative strategies for improvement (DarlingHammond \& Bransford, 2005). Self-reflection contributes significantly to the rigour of any TE programme, including PGCE.

Some of the participants expressed contentment with the amount of knowledge gained in the pedagogical domain and other curriculum areas. For example, of the 19 beginner teachers, 12 of them (approximately 63\%), six from institution A and six from institution B, expressed dissatisfaction with the superficial nature of the practical knowledge domain. They highlighted a disjuncture between the vast amount of time spent on the theory and the short span of time spent in schools during TP in the PGCE programme. One of the beginner teachers from institution $\mathrm{A}$, Andre, made a statement that was echoed by all 12 participants:

While the PGCE had depth in most of the areas, teaching practice was a challenge to me, especially during the first semester. Although we did microteaching in other subject didactics, it was different from the real classroom where you have to deal with children. The worse (sic) thing was that because we spent very little time in schools practising teaching, we were assessed very early while we [were] still trying to understand how to apply new concepts in the classroom, which caused a lot of anxiety especially during the first term.

Andre's comment seems to imply that they (students) had insufficient opportunities to explore and apply the theoretical aspects and principles that guide teaching practice to provide positive learning experiences for novice teachers (LaBoskey \& Richert, 2002). It indicates the complexity of teaching, which requires simultaneous management of knowledge and children. It also reflects contextual and programmatic tensions in learning to teach as alluded to by Samuel (2008). Specifically, there seems to be a conflict between the institutional and programmatic forces on the one hand and the context in which the student teachers were expected to teach. Hence, students seemed to struggle to make meaningful connection between knowledge-of-practice and knowledge-for-practice (Cochran-Smith \& Lytle, 1999). When the duration of TP in B.Ed. and PGCE TP is compared, the short span of TP in PGCE provides a valid reason for the basis of beginner teachers' dissatisfaction with the lack of rigour of the practical knowledge domain.

Exposure to practical knowledge provides students with authentic contexts in which to apply theoretical knowledge gained in university classrooms and interact with other CoTP members (Lave \& Wenger, 1999). Students acquire the skills and attitudes needed to become fully-fledged members of a CoTP, able to solve problems associated with teaching and learning contexts (Reyes \& Fagan, 2010). According to Darling-Hammond and Bransford (2005), supervision and feedback from mentor teachers constitute rigour which is essential for beginner teachers to become effective teachers. Teaching experience does not automatically translate into good practice (Darling-Hammond \& Bransford, 2005). Students need optimal opportunities to practise teaching, receive feedback which helps them make sense of their practice and reflect on their work in order to develop a solid understanding, interpretation and application of teaching and learning concepts in new situations (Kemmis, 2011; Grosser \& De Waal, 2008; Korthagen \& Kessels, 1999). In this way, they learn to connect theoretical knowledge and pratice, especially if teaching practice runs concurrently with coursework (Darling-Hammnond \& Bransford, 2005). With only eight or nine weeks of TP expressed earlier, providing students with adequate opportunities for making meaningful connections between 
theory and practice may not be possible unless the current PGCE model is revisited to balance knowledge-of-practice and knowledge-in-practice. It should focus on a deep understanding of content knowledge; possession of general pedagogical knowledge or knowledge about teaching and a good understanding of learners and contexts (Shulman, 1987). The programme should include curriculum knowledge, pedagogical content knowledge (PCK), which combines content and pedagogical domains and knowledge of educational ends, purposes and values.

\section{Discussion}

In this paper, we have shown that beginner teachers have their own ideas, definitions and assumptions about rigour of the PGCE programme, as experienced by them in their practical engagements in the classrooms. Unlike the theoretical views expressed by experts on what counts as rigour of ITE, participants' perspectives were informed by their disciplinary/ theoretical knowledge and pragmatic classroom knowledge during TP and by the school contexts in which they taught. In this study, experts' conceptions of rigour formed the basis upon which beginner teachers' perspectives on this topic were analysed.

Participants' perceptions of depth and rigour varied, as did perceptions of experts in TE. For example, some participants mentioned that the PGCE programme had equipped them with rigorous knowledge and skills in various learning areas. From these accounts, one can deduce that they understood rigour in relation to the scope of the programme offerings. The wider the scope of the offerings, the more rigourous the programme was and vice versa. This perception is logical, considering that Slonimsky and Shalem (2006) emphasise deepening students' knowledge and learning.

Data obtained from beginner teachers suggests that for them, rigour constitutes horizontal and vertical dimensions, that is, how deep they wanted teacher educators to delve into the knowledge domains and how broad the scope of that knowledge was. The knowledge domains that they wanted prioritised in the PGCE programme constituted rigour for them. Similarly, they appeared to have associated their access to new education concepts and skills (critical thinking, creativity, problem solving and decision making) with the rigour of the PGCE programme. Reyes and Fagan (2010) and Jacobs and Colvin (2010) agree that a combination of these skills amounts to rigour which they believe increases beginner teachers' epistemological access to knowledge.

Participants appeared to view the short span of the PGCE as a limitation of the ITE programme. It appears that if the programme had been spread over a longer period of time, participants may have been able to have a deeper engagement with teacher education concepts over time. It could be possible that beginner teachers understood rigour not only in terms of the scope of the programme offerings mentioned earlier but its duration as well. The fact that participants recognised the richness of the knowledge they gained in the pedagogical knowledge domain may suggest that the richer the programme is, the more rigourous it is and vice versa. Participants defined rigour in relation to the inclusion of situational knowledge and exposure to practical knowledge. Indeed, literature on rigour confirms that learning to teach is a cognitive and social process involving theory and practice (Lave \& Wenger, 1999; DarlingHammond \& Bransford, 2005).

Participants obtained PGCE qualifications from different institutions, yet their views on what constitutes rigour were quite similar. This could be an indication that there are some 
commonalities between curriculum practices in the PGCE programmes. This may suggest that the knowledge and skills they gained prior to becoming credentialed teachers might have influenced their classroom practices in more or less the same way, leading them to reach similar opinions about what constitutes rigour of the PGCE ITE programme.

\section{Conclusion}

We acknowledge that teaching is a complex activity and that theories provided by TE policymakers and experts about what constitutes rigour in ITE are significant. Because these theories and conceptions about what constitutes rigour in teacher education are based on and confirmed by empirical research, they possess legitimacy. Nonetheless, the voices of beginner teachers and other stakeholders at grassroots' level should be heard in ITE curriculum design. We recommend that beginner teachers and other stakeholders in ITE (teacher educators, mentor teachers, school principals and communities) be afforded opportunities to voice their perceptions of what rigour in ITE means to them. Having said this, it should be borne in mind that students and other stakeholders' conceptions of rigour may not be informed by theoretical underpinnings and can therefore not supersede those of the experts. Therefore, experts on ITE should lead the process of teacher education policy formulation and implementation, as they have deeper theoretical understandings of rigour in teacher education but be aware of the way that students are experiencing the demands, conceptual progression and contextual limitations of the designed curriculum.

The findings of this paper are not generalisable to other contexts due to the small sample that was used. Nonetheless, they are significant in understanding the strengths and limitations of the PGCE programme from the beginner teachers' perspectives with regard to the rigour of these programmes. In a way, they illustrate that although ITE programmes prepare teachers for teaching, they nevertheless do not fully prepare them for the realities of the classroom. These perspectives highlight implications for policies underpinning ITE programmes and for teacher educators' understanding of how students learn to teach. More studies on ITE should consider student and beginner teachers' voices in order to gain new insights into how policy and practice could be improved for the benefit of all ITE stakeholders. There is a need to conduct broader studies that could be generalised to other contexts.

\section{References}

Ashby, P., Hobson, A.J., Tracey, L., Malderez, A., Tomlinson, P.D., Roper, T., Chambers, G.N. \& Healy, J. 2008. Beginner teachers' experiences of initial teacher preparation, induction and early professional development: A review of literature. Commissioned Report. University of Nottingham: Department for Education and Skills (DfES).

Babbie, E. \& Mouton, J. 2001. Methodological paradigms in social research, in the practice of social science. South Africa: Oxford University Press Southern Africa.

Ben-Peretz, M. 2011. Teacher knowledge: What is it? How do we uncover it? What are its implications for schooling? Teaching and Teacher Education, 27, 3-9. http://dx.doi. org/10.1016/j.tate.2010.07.015

Berliner, D.C. 2004. Describing the behaviour and documenting the accomplishments of expert teachers. Bulletin of Science, Technology \& Society, 24(3), 200-212. http://dx.doi. org/10.1177/0270467604265535 
Blömeke, S. \& Kaiser, G. 2014. Theoretical framework, study design and main results of TEDS-M. In S. Blömeke, F.J. Hsieh, G. Kaiser \& W.H. Schmidt (Eds.). International perspectives on teacher knowledge, beliefs and opportunities to learn. Dordrecht, Heidelberg: Springer. pp. 19-48. http://dx.doi.org/10.1007/978-94-007-6437-8_2

Britzman, D.P. 2003. Practice makes practice: A critical study of learning to teach. Albany, NY: State University of New York Press.

Buehler, J., Ruggles-Gere, A., Dallavis, C. \& Shaw-Haviland, V. 2009. Normalizing the fraughtness: How emotion, race, and school context complicate cultural competence. Journal of Teacher Education, 60(4), 408- 418. http://dx.doi.org/10.1177/0022487109339905

Cochran-Smith, M. 2001. Constructing outcomes in teacher education: Policy, practice and pitfalls. Education Policy Analysis Archives, 9(11), 1-56. http://dx.doi.org/10.14507/epaa. v9n11.2001

Cochran-Smith, M. \& Lytle, S.L. 1999. Relationship of knowledge and practice: Teacher learning in communities. Review of Research in Education, 24, 249-305. http://dx.doi. org/10.2307/1167272

Colvin, R.L. \& Jacobs, J. 2010. Rigor: It's all the rage, but what does it mean? Available at http://hechingerreport.org/rigor-its-all-the-rage-but-does-it-mean/. [Accessed 3 November 2015].

Darling-Hammond, L. \& Bransford, J. 2005 (Eds.). Preparing teachers for a changing world. San Francisco: Jossey-Bass.

Department of Education (DoE). 1997. Education White Paper 3: A programme for the transformation of higher education. Pretoria: Department of Education.

Department of Higher Education and Training (DHET). 2011. National qualifications framework, Act 67 of 2008. Revised policy on the minimum requirements for teacher education qualifications. Pretoria: Government Printers.

Department of Higher Education and Training (DHET). 2015. National qualifications framework, Act 67 of 2008. Policy on the minimum requirements for teacher education qualifications. Pretoria: Government Printers.

Feiman-Nemser, S. 2001a. From preparation to practice: Designing a continuum to strengthen and sustain teaching. Teachers College Record, 103(6), 1013-1055. http://dx.doi. org/10.1111/0161-4681.00141

Feiman-Nemser, S. 2001b. Helping novices learn to teach. Lessons from an exemplary support teacher. Journal of Teacher Education, 52(1), 17-30. http://dx.doi. org/10.1177/0022487101052001003

Fitzmaurice, M. 2010. Considering teaching in higher education as a practice. Teaching in Higher Education, 15(1), 45-55. http://dx.doi.org/10.1080/13562510903487941

Grosser, M. \& De Waal, E. 2008. Recentering the teacher: From transmitter of knowledge to mediator of learning. Education as Change, 12(2), 41-57. http://dx.doi. org/10.1080/16823200809487206

Hammerness, K., Darling-Hammond, L., Bransford, J., Berliner, D., Cochran-Smith, M, McDonald, M. \& Zeichner, K. 2005. How teachers learn and develop. In L. Darling Hammond 
\& J. Bransford (Eds.). Preparing teachers for a changing world: What teachers should learn and be able to do. San Francisco: Jossey-Bass Publishers. pp.359-389.

Hoban, G. 2004. Seeking quality in teacher education design: A four dimensional approach. Australian JournalofEducation,48(2), 117-133.http://dx.doi.org/10.1177/000494410404800203

Jacobs, J. \& Colvin, R.L. 2010. Rigor: It's all the rage, but what does it mean? Understanding and reporting on academic rigor. Columbia: Columbia University Teachers College.

Kanjee, A., Sayed, Y. \& Rodriguez, D. 2010. Curriculum planning and reform in sub-Saharan Africa. Southern African Review of Education, 16(1), 83-96.

Kemmis, S. 2011. What is professional practice? Recognizing and respecting diversity in understandings of practice. In C. Kanes (Ed.). Elaborating professionalism: Studies in practice and theory. New York: Springer, pp. 139-165.

Kerry, T. \& Mayes, A.S. (Eds.). 1995. Issues in mentoring. London: Routledge.

Korthagen. F.A. \& Kessels, J.P.A.M. 1999. Linking theory and practice. Changing the pedagogy of teacher education. Educational Researcher, 4, 4-7. http://dx.doi. org/10.3102/0013189X028004004

Kwenda, C. \& Robinson, M. 2010. Initial teacher education in selected southern and east African countries: Common issues and ongoing challenges. Southern African Review of Education, 16(1), 97-113.

LaBoskey, V.K. \& Richert, A.E. 2002. Identifying good student teaching placements: A programmatic perspective. Teacher Education Quarterly, 29(2), 7-34.

Lave, J. \& Wenger, E. 1999. Situated learning: Legitimate peripheral participation. Cambridge, UK: Cambridge University Press.

Lawrence, M. \& Butler, M. 2010. Becoming aware of the challenges of helping students learn: An examination of the nature of learning during a service learning experience. Teacher Education Quarterly, 37(1), 1-22.

Lortie, D. 1975. School teachers: A sociological study. Chicago: University of Chicago Press.

Madisaotsile, B.M. 2012. The failing standard of basic education in South Africa. Policy Brief. Africa Institute of South Africa (AISA) Briefing, 72, 1-7.

Marcelo, C. 2009. Professional development of teachers: Past and future. Sísifo/ Educational Sciences Journal, 8, 5-20.

Morrow, W. 2007. What is teachers' work? Journal of Education, 41, 3-20.

Pournara, C. 2009. Developing a new pre-service secondary mathematics teacher education programme: Principles for content selection and emergent tensions. Education as Change, 13(2), 293-307. http://dx.doi.org/10.1080/16823200903234836

Reyes, N.O. \& Fagan, S. 2010. Transforming our teaching and learning: The role of academic rigor, inquiry and higher order thinking. MCCCD Educational Council Summer Report.

Rusznyak, L. 2009. Confronting the 'pedagogical immunity' of student teachers. Education as Change, 13(2), 263-276. http://dx.doi.org/10.1080/16823200903234794 
Rusznyak, L. 2015. Knowledge selection in initial teacher education programmes and its implications for curricular coherence. Journal of Education, 60, 7-20.

Samuel, M. 2008. Accountability to whom? For what? Teacher identity and the force field model of teacher development. Perspectives in Education, 26(2), 3-16.

Sayed, Y. \& Motala, S. 2012. Getting in and staying there: Exclusion and inclusion in South African schools. Southern African Review of Education, 18(2), 105-118.

Schön, D.R. 1987. Educating the reflective practitioner: Toward a new design for teaching and learning in the profession. San Francisco, CA: Jossey-Bass.

Shulman, L.S. 1987. Knowledge and teaching: Foundations of the new reform. Harvard Education Review, 57(1), 1-22. http://dx.doi.org/10.17763/haer.57.1.j463w79r56455411

Slonimsky, L. \& Shalem, Y. 2006. Pedagogic responsiveness for academic depth. Journal of Education, 40, 35-58.

Sosibo, Z. \& Nomlomo, V. 2014. Teachers' conceptions of standards in South African basic education and training: A case study. Perspectives in Education, 32(1), 77-91.

Verloop, N., Van Driel, J. \& Meijer, P. 2001. Teacher knowledge and the knowledge base of teaching. International Journal of Educational Research, 35, 441-461. http://dx.doi. org/10.1016/S0883-0355(02)00003-4 